\title{
PENGARUH ENDORPHINE MASSAGE TERHADAP KECEMASAN PASIEN PRE SECTIO CAESAREA DI RSUD ENGKU HAJI DAUD
}

\author{
${ }^{1)}$ Arum Dwi Anjani, ${ }^{2)}$ Devy Lestari Nurul Aulia, ${ }^{3)}$ Risqi Utami, ${ }^{4)}$ Maya Sumanti \\ Program Studi Kebidanan Fakultas Kedokteran Universitas Batam \\ J1. Abulyatama No.5 Batam 29464 \\ Email : ${ }^{1)}$ arum.dwianjani05@univbatam.ac.id, ${ }^{2)}$ dv.aulia87@univbatam.ac.id,

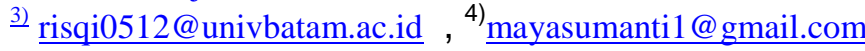

Kata Kunci:

Kecemasan, endorphine massage, Sectio

Caesarea

Keywords:

Anxiety, endorphine

massage, Sectio Caesarea

\section{Info Artikel}

Tanggal dikirim: 28-7-2021

Tanggal direvisi: $16-8-2021$

Tanggal diterima: 23-1-2022

DOI Artikel:

10.36341/jomis.v6i1.1946

Creative Commons AttributionNonCommercial-ShareAlike 4.0 International License.

\begin{abstract}
ABSTRAK
Pada saat persiapan operasi sectio caesarea, pasien akan dihadapkan dengan bayangan mengenai proses operasi, keselamatan bayi, keselamatan dirinya, kesakitan serta berbagai masalah lain yang akan membuat pasien mengalami ketidaknyamanan dan menjadi sebuah kecemasan. Kecemasan pre operasi yang tidak dapat diatasi dapat menimbulkan komplikasi yang berakibat pada penundaan operasi. Oleh karena itu, kecemasan pada ibu pre operasi section caesarea harus diatasi, salah satunya dengan intervensi endorphine massage. Penelitian ini bertujuan untuk mengetahui pengaruh endorphine massage terhadap tingkat kecemasan pada ibu pre Sectio Caesaria. Penelitian ini menggunakan metode quasi-eksperimen dengan rancangan pra - pasca test (one grup - pre test - post test design). Penelitian ini dilakukan pada bulan Oktober 2020- Februari 2021 di RSUD Engku Haji Daud Tanjung Uban. Populasi dalam penelitian ini adalah ibu hamil pre sectio cesarea sebanyak 20 responden. Sampel diambil menggunakan total sampling. Hasil penelitian menunjukkan rata-rata skor kecemasan sebelum intervensi endorphine massage adalah sebesar 21,85, sedangkan sesudah intervensi endorphine massage adalah sebesar 12,85, hasil ini menunjukkan selisih rata-rata skor kecemasan pada ibu pre sectio cesarea adalah sebesar 9. Hasil uji statistic dengan Wilcoxon test menunjukkan nilai $\mathrm{p}<0,05$, kesimpulannya ada pengaruh endorphine massage terhadap tingkat kecemasan pada ibu pre Sectio Caesaria. Disarankan pada ibu agar dapat mengaplikasikan teknik endorphine massage untuk mengurangi kecemasan dapat juga dilakukan di rumah.
\end{abstract}

\begin{abstract}
Riskesdas 2018 data from Riau Archipelago Province shows that the most Sectio Caesarea deliveries occur to mothers with an age range of 45-49 years (27.66\%), education D1/D2/D3/PT (36.95\%), most occupations are private employees (42.30\%), and live in urban areas $(24.6 \%)$. When preparing for a cesarean section, the patient will be faced with the operation process, the safety of the baby, and himself. Untreated preoperative anxiety can lead to complications that result in surgery delays. Therefore, anxiety in preoperative caesarean section mothers must be overcome, one of which is endorphin massage intervention. This study aims to determine the effect of endorphine massage on the anxiety level of pre Sectio Caesaria mothers. The study used a quasiexperimental method with a pre-post-test design (one group - pre-test - post-test design). The study was conducted in October 2020-February 2021 at Engku Haji Daud Tanjung Uban Hospital. The study population was pregnant women with pre sectio caesarea 20 respondents. The sample uses total sampling. The results showed that the average anxiety before the endorphine massage intervention was 21.85, while after the intervention was 12.85, this result showed the difference in the average anxiety score for pre-cesarean mothers was 9. The results of the Wilcoxon test statistic test showed the $p<0.05$, the conclusion is that there is an effect of endorphine massage on anxiety levels in pre Sectio Caesaria mothers. It is recommended for mothers to be able to apply endorphine massage techniques to reduce anxiety, it can also be done at home.
\end{abstract}




\section{PENDAHULUAN}

Sectio Caesarea adalah merupakan tindakan medis yang dilakukan suatu pembedahan untuk melahirkan janin lewat insisi dinding abdomen dan uterus[1]. Di Rumah sakit milik Pemerintah Terdapat $20-$ $25 \%$ dari total persalinan yang menjalani Sectio Caecarea, Sedangkan terdapat $30-80$ $\%$ dari total persalinan yang menjalani Sectio Caesarea di rumah sakit swasta. Data tersebut lebih tinggi dibandingkan dengan standar Kementrian Kesehatan yaitu persalinan Sectio Caesarea adalah kurang dari 20\%[2]

Berdasarkan Riset Kesehatan Dasar Nasional Tahun 2018 didapatkan data rata-rata angka kejadian persalinan Sectio Caesarea di Indonesia adalah sebesar $17.6 \%$. Angka persalinan Sectio Caesarea terkecil adalah di Provinsi Papua sebesar $6.7 \%$ dan tertinggi adalah di Provinsi DKI Jakarta berjumlah "31.1\%". Sedangkan untuk Provinsi Kepulauan Riau sendiri angka kejadian persalinan Sectio Caesarea sebesar 23.7\% [3]

Data Riskesdas 2018 Provinsi Kepulauan Riau juga menunjukkan bahwa persalinan Sectio Caesarea terbanyak terjadi pada ibu dengan rentang usia 45-49 tahun (27.66\%), pendidikan D1/D2/D3/PT (36.95\%), pekerjaan terbanyak adalah pegawai swasta (42.30\%), dan paling banyak bertempat tinggal di perkotaan $(24.6 \%)$ [3]

Dalam menghadapi persiapan operasi sectio caesarea, pasien akan membayangkan proses pembedahan, saat pembiusan, kesejahteraan bayi, Keamanan ibu, kesakitan dan berbagai ketidaknyaman yang lainnya, yang membuat pasien menjadi cemas. Kecemasan menjelang persalinan dapat berupa perasaan kecemasan akan keselamatan ibu dan bayinya, ketakutan akan keadaan patologis atau lahir cacat, rasa bersalah terhadap orang tua atau dosa-dosa masa lalu[4]

Kecemasan merupakan perasaan dan pengalaman pribadi seseorang yang menyebabkan rasa tidak nyaman dan diklasifikasikan kedalam beberapa tingkatan[5]. Tanda dan Gejala kecemasan yang sering muncul yaitu berkeringat, denyut jantung meningkat, kelelahan, vertigo, diare, sesak nafas, mual-mual gemetaran, kejang, sakit kepala, Kesulitan tidur[6] Kecemasan dapat juga menyebabkan adanya perubahan pada fisik dan psikologis hal ini dapat dilihat dari meingkatnya denyut jantung, meningkatnya tekanan darah, bernafas cepat dan rasa kelelahan pada pasien[7].

Dalam menghadapi persalinan, ibu hamil sering merasa cemas, terutama pada ibu primigravida. Rasa cemas biasanya akan meningkat pada kehamilan trimester III, yang disebabkan adanya perasaan khawatir akan jalannya persalinan, rasa sakit dan perawatan bayi[8]

Manajemen kecemasan saat sebelum operasi yang dapat dilakukan yaitu terapi farmakologis maupun non farmakologis. Akan tetapi pemberian obat - obatan pada ibu hamil perlu di batasi. Terapi non obat - obatan yang dapat digunakan untuk mengurangi kecemasan salah satunya adalah masase.[9]

Dalam mengatasi kecemasan ibu hamil yang akan menghadapi persalinan dapat diberikan terapi non farmakologi untuk mengontrol perasaan cemas ibu. Menurut AAMT, 2016 telah mendaftarkan metode terapi non farmakologi seperti relaksasi, akupuntur, massage, kompres hangat, aroma terapi. Endorphine massage adalah cara untuk menghilangkan kecemasan [10]. Hal ini sesuai dengan penelitian oleh Sukmaningtyas \& Windiarti (2016) bahwa teknik massage membantu ibu hamil merasa nyaman, rileks, dan lebih segar selama proses persalinan.[11]

Massase merupakan teknik yang digunakan untuk meredakan rasa tidak nyaman saat persalinan melaui permukaan kulit. Saat persalinan, masase dapat berperan sebagi analgesik untuk mengurangi nyeri dan stress serta memberikan rasa nyaman. endorphin massage merupakan salah satu teknik yang dapat dilakukan yaitu suatu cara dengan melakukan sentuhan ringan yang digunakan untuk mengurangi rasa sakit dan mengurangi kecemasan. [12]

Menurut penelitian yang dilakukan oleh Dian tahun 2017 dengan judul "Pengaruh Massage Endorphin terhadap Penurunan Tingkat Kecemasan pada Persalinan Kala I di Wilayah Kerja Puskesmas Kecamatan Kemiri”" 
didapatkan hasil yang menunjukkan kecemasan ibu bersalin kala I sebelum diberikan endorphine Massase sebagian besar mengalami kecemasan berat yaitu sebanyak 16 responden $(50 \%)$ dan setelah diberikan perlakukan mayoritas responden mengalami kesemasan sedang yaitu sebanyak 15 responden (46,9\%).[4]

Berdasarkan data terdahulu yang dilakukan oleh peneliti, dari 5 orang ibu pre operasi SC di ruang kebidanan RSUD EHD Tanjung Uban didapatkan bahwa 4 orang (80\%) mengalami kecemasan sedang, dan 1 orang $(20 \%)$ mengalami kecemasan berat. Respon cemas pada ibu terlihat pada peningkatan tekanan darah, merasa tegang, gemetar, dan tidak dapat beristirahat dengan tenang. Hasil wawancara peneliti dengan ibu menunjukkan bahwa sebagaian besar alasan ibu merasa cemas karena takut akan nyeri paska operasi dan komplikasi lain seperti infeksi pada luka operasi sehingga lama sembuh. Ibu mengatakan bahwa kecemasan timbul karena mendengar berbagai mitos terkait dengan operasi dari orang lain. Jika kecemasan ibu pre operasi tidak diatasi maka dapat berakibat terganggunya intervensi yang akan diberikan seperti penundaan operasi sementara sampai kondisi ibu baik salah satunya dengan indikator tekanan darah yang stabil.[13]

Intervensi yang dilakukan bidan untuk mengatasi kecemasan ibu pre operasi SC adalah dengan meminta support suami dan keluarga. Penelitian tentang intervensi endorphine massage untuk mengatasi kecemasan pada ibu pre operasi SC di RSUD Engku Haji Daud Tanjung Uban belum pernah dilakukan.

Berdasarkan fenomena tersebut peneliti tertarik untuk melakukan penelitian tentang pengaruh endorphine massage terhadap penurunan kecemasan pada ibu pre operasi Sectio Caesaria di ruang Kebidanan RSUD Engku Haji Daud Tanjung Uban

Tujuan Penelitian untuk mengetahui pengaruh endorphine massage terhadap kecemasan pada ibu pre operasi Sectio Caesaria di ruang Kebidanan Rumah Sakit
Umum Daerah Engku Haji Daud Tanjung Uban

\section{TINJAUAN PUSTAKA}

Adanya hambatan atau kelainan dalam proses persalinan, yang mengakibatkan bayi tidak dapat lahir secara spontan, contohnya Mal presentasi janain, pre eklamsi, distosia serviks, Partus lama, panggul sempit, partus tak maju, plasenta previa, diaproporsi. Kondisi ini mengakibatkan pernya suatu tindakan pembedahan atau sectio secarea[1]

Dalam proses pembedahan atau SC akan dilakukan anastesi yang mengakibatkan pasien merasakan imobilisasi sehingga menimbulkan Intoleransi aktifitas. Efek samping anastesi juga menimbuknan relaksasi otot dan mengakibatkan konstipasi. Kurangnya informasi yang di dapatkan pasien tentang proses pembedahan, perwatan post sc dan masa penyembuhan menyebabkan masalah ansietas. Proses SC juga dilakukan tindakan insisi pada dinding perut sehingga mengakibatkan inkontiniuitas jaringan, sarat dan pembuluh darah disekitarnya. Hal ini merangsang pengeluaran prostaglandin dan histamin yang menimbulkan rasa tidak nyaman dan nyeri [1]

Tindakan Pembedahan atau SC menyebabkan komplikasi yaitu rusaknya vesika urunaria dan uterus, perdarahan, kompplikasi anastesi, tromboemboli dan infeksi. Dibandingkan persalinan pervaginam ,kematian ibu lebih besar pada persalinan sc. TKejadian trauma persalinan dan akipnea pada bayi baru lahir pun lebih sering terjadi pada persalinan sc. Resiko jangka panjang yang dapat mengikuti persalinan sc antara lain solusio plasenta, plasenta previa, plasenta akreta dan ruptur uteri [14]

Jong dalam Effendi (2015) mengatakan bahwa operasi tidak dapat dilaksanakan jika kecemasan pre operasi sangat hebat karena 
dapat menyebabkan tekanan darah meningkat dan jika tetap dilaksanakan operasi akan menyebabkan penyulit saat proses operasi dan mempengaruhi saat pemulihan[15]

Indikasi endorphin massage dilakukan pada ibu hamil diatas usia kehamilan 36 minggu. endorphin massage dapat mendorong keluarnya hormon endorphin dan oksitosin yang dapat merangsang kontraksi [12]

Menurut yusuf (2015) kecemasan merupakan perasaan tidak santai akibat keridaknyamanan atau rasa takut disertai respon yang penyebab nya tidak diketahui individu. Rasa takut sebagai sinyal peringatan bahaya yang datang dan menyebabkan individu mengambil tindakan untuk menghadapi ancaman[16]

Teori endorphin massage adalah otot polos berada dibawah kulit (pilus elektor) bereaksi kontraksi saat di rangsang. hal ini terjasi saat otot menarikrambut yang berada di permukaan yang menegang dan menyebabkan buku kuduk berdiri, berdirinya bulu kuduk, merangasng terbentuknya hormon endorphin yang menyebabkan relaksasi [17]

Endorphine massage merupakan metode sentuhan ringan yang di peruntukkan meredakan rasa sakit. teknik ini bisa digunakan sebagai alternatif mengurangi rasa nyeri saat persalinan berlangsung dan meningkatkan rasa nyaman melalui permukaan kulit. Teknik ini juga dapat mnormalkan tekanan darah dan dednyut jantung [12]

Berdasarkan data terdahulu yang dilakukan oleh peneliti, dari 5 orang ibu pre SC di ruang kebidanan RSUD EHD Tanjung Uban didapatkan bahwa 4 orang (80\%) mengalami kecemasan sedang, dan 1 orang (20\%) mengalami kecemasan berat. Respon cemas pada ibu terlihat pada peningkatan tekanan darah, merasa tegang, gemetar, dan tidak dapat beristirahat dengan tenang.
Menurut penelitian oleh Dian (2017) dengan judul "Pengaruh Massage Endorphin terhadap Penurunan Tingkat Kecemasan pada Persalinan Kala I di Wilayah Kerja Puskesmas Kecamatan Kemiri" hasil penelitiannya menunjukkan jumlah ibu bersalin kala I sebelum diberikan terapi massage endorphine paling banyak mengalami kecemasan berat sebanyak 16 orang (50\%) dan sesudah diberikan treatment mayoritas mengalami kecemasan sedang yaitu sebanyak 15 orang $(46,9 \%) .[4]$

Penelitian Afifatu Rohmah, Sri Hendarsih, dan Ana Ratnawati (2019) yang berjudul "Pengaruh Pemberian Endorphin Massage Terhadap Tingkat Kecemasan Pasien Pre SC Di RSU Siaga Medika Banyumas" didapatkan hasil bahwa adanya pengaruh endorphin massage terhadap tingkat kecemasan pasien pre sectio caesarea $(\mathrm{p}=$ 0,40). Penelitian ini merupakan penelitian kuantitatif dengan rancangan penelitian pre test dan post test dengan kelompok kontrol. Penelitian ini dilaksanakan pada bulan MaretApril 2019. Teknik pengambilan sampel yang digunakan yaitu consecutive sampling. Sampel dari penelitian ini sejumlah 36 responden yang terdiri dari 18 responden kelompok intervensi dan 18 responden kelompok kontrol. Uji statistik yang digunakan yaitu uji wilcoxon[18]

Diana Arianti \& Ledia Restipa (2019) yang berjudul "Pengaruh Endorphine Massage Terhadap Tingkat Kecemasan Ibu Primigravida" didapatkan hasil bahwa nilai rata-rata kecemasan pada kelompok perlakuan adalah 0,667 , dan rata-rata tingkat kecemasan pada kelompok kontrol adalah 0,267. Hasil analisa uji $t$-test didapatkan nilai $\mathrm{p}$ value 0,003 $(\mathrm{p}<0,05)$. Artinya terdapat tingkat kecemasan yang bermakna pada kelompok eksperimen sebelum dan sesudah diberi massage endorphine. Berdasarkan uji t-test diperoleh 
nilai $\mathrm{p}$ value $0,041(\mathrm{p}<0,05)$. Jenis penelitian ini kuatitatif dengan Quasi Eksperiment dengan rancangan two group pretest-Posttest Design. Jumlah sampel penelitian 30 responden dengsan teknik pengambilan sampel secara purposive sampling. Penelitian ini dilaksanakan bulan Maret- Agustus 2019 di bidan praktek swasta yang ada diwilayah kerja Puskesmas Dadok Tunggul Hitam Kota Padang[19]

Penelitian Luh Putu Widiastini (2017) yang berjudul "Pengaruh Massage Endorphin Terhadap Kecemasan Ibu Hamil Dalam Menghadapi Proses Persalinan Di Puskesmas Denpasar Utara III" berdasarkan hasil uji independent t-test didapatkan hasil bahwa ada penurunan tingkat kecemasan ibu hamil pada kelompok intervensi dibandingkan dengan kelompok kontrol ( $\mathrm{p}<0.05)$ artinya ada pengaruh Massage Endorphin Terhadap Kecemasan Ibu Hamil Dalam Menghadapi Proses Persalinan.[20]

Sri Rahayu, Melyana Nurul Widyawati, dan Retno Kusuma Dewi (2018) yang berjudul " Pengaruh Masase Endorphin terhadap Tingkat Kecemasan dan Involusio Uteri Ibu Nifas" didapatkan hasil bahwa sebagian besar responden pada kelompok perlakuan dari $69 \%$ yang mengalami kecemasan sedang, setelah adanya intervensi masase endorphin $61,5 \%$ tidak cemas dan proses involusio uteri pada kelompok perlakuan terjadi penurunan TFU menjadi 6,58 cm, sedangkan pada kelompok kontrol penurunan TFU menjadi $7 \mathrm{~cm}$. Antara kelompok perlakuan dan kontrol terjadi rerata selisih penurunan TFU sebesar $0,54 \mathrm{~cm}$, lebih cepat pada kelompok perlakuan[21]

Penelitian Dinda Restianti, Herniyatun, dan Dadi Santoso (2017) yang berjudul "Perbandingan Efektifitas Antara Pijat Endorfin Dengan Aromaterapi Lavender Terhadap Intensitas Nyeri Pasca Sectio
Caesarea Di RS PKU Muhammadiyah Gombong" didapatkan hasil bahwa setelah diberikan pijat endorfin terjadi penurunan ratarata intensitas nyeri pasca Sectio Caesarea dari 4,5 menjadi 3 dengan perbedaan mean sebesar 1,611. Sedangkan, setelah diberikan aromaterapi lavender rata- rata intensitas nyeri menurun dari 4,5 menjadi 3,25 dengan perbedaan mean 1,277. Kesimpulan penelitian adalah tidak terdapat perbedaan yang signifikan keefektifan penurunan intensitas nyeri pemberian pijat endorfin dibandingkan aroma terapi lavender pada pasien pasca Sectio Caesarea dengan $\mathrm{p}=0,149(\mathrm{p}<0,05)[22]$

Penelitian R. Khairiyatul Afiyah (2019) yang berjudul "Demonstrasi Endorphin Massage Untuk Mengurangi Kecemasan Menghadapi Persalinan Pada Primigravida Di Poli KIA RS Islam Surabaya" didapatkan hasil bahwa hasil pre test responden tentang endorphine massage dengan hasil hampir seluruhnya $(77.1 \%)$ mempunyai pengetahuan kurang. Sedangkan berdasarkan hasil post test responden tentang endorphine massage dengan hasil hampir seluruhnya $(71.4 \%)$ mempunyai pengetahuan baik[8]

Penelitian Pande Putu Novi Ekajayanti (2016) yang berjudul "Pemberian Endorphin Massage Mempengaruhi Kesiapan Psikologi Ibu Hamil TM III Dalam Menghadapi Persalinan Di BPM NWB Kintamani” didapatkan hasil bahwa sebelum diberikan Endorphin Massage yaitu dengan kategori siap sebanyak 8,3\% (3 orang), kategori kurang siap sebanyak 55,6\% (20 orang), dan kategori tidak siap sebanyak 36,1\% (13 orang). Sedangkan setelah diberikan Endorphin Massage yaitu dengan kategori siap sebanyak 83,3\% ( 30 orang), kategori kurang siap sebanyak 13,9\% (5 orang), dan kategori tidak siap sebanyak 2,8\% (1 orang). Kesimpulan penelitian bahwa Endorphin Massage mempengaruhi Kesiapan 
Psikologi Ibu Hamil TM III Dalam Menghadapi Persalinan Di BPM[13]

Penelitian Sri Wuryani, Dian Qur'aini, Nila Fatmawati dan Rika Aprilia (2015) yang berjudul "Pengaruh Terapi Relaksasi Masase Punggung Terhadap Penurunan Tingkat Kecemasan Pada Pasien Pre Operasi Bedah Mayor Di SMC RS Telogorejo" didapatkan hasil bahwa rata-rata skor rentang kecemasan sebelum melakukan relaksasi masase punggung yaitu sebesar 43,44 setelah dilakukan relaksasi masase punggung turun menjadi 29,03, perbedaan kecemasan sebelum dan sesudah perlakuan yaitu sebesar 14,41 yang artinya terdapat pengaruh yang signifikan sebelum dan sesudah dilakukan relaksasi masase punggung pada pasien pre operasi bedah mayor dengan $\mathrm{p}=0,000$ atau $<0,05$.[23]

Dapat disimpulkan penerapan Massage Endorphin sangat berpengaruh signifikan terhadap penurunan Kecemasan pada Ibu yang bersalin.

\section{METODE}

Penelitian ini menggunakan rancangan pra pasca test dalam satu kelompok (one grup pre test - post test design) dengan metode quasi-eksperimen Metode sampel adalah total sampling dan diperoleh 20 responden ibu pre Sectio Caesarea. Pengumpulan data dilakukan mulai tanggal 28 Desember 2020 sampai dengan 28 Januari 2021. Hasil uji statistic dengan Wilcoxon test

\section{HASIL DAN PEMBAHASAN}

Tabel 1

Karakteristik Responden Berdasarkan Umur dan Paritas di Ruang Kebidanan RSUD EHD Tanjung Uban $(n=20)$

\begin{tabular}{ccccc}
\hline \multicolumn{1}{c}{$\boldsymbol{N}$} & $\begin{array}{l}\text { Varia } \\
\text { o }\end{array}$ & $\begin{array}{c}\boldsymbol{M} \\
\text { bel }\end{array}$ & $\begin{array}{c}\text { Medi } \\
\text { ean }\end{array}$ & $\begin{array}{c}\text { Min } \\
\text { anx }\end{array}$ \\
\hline 1 & Umur & 30, & 29 & $22-$ \\
& & 80 & & 47 \\
2 & Paritas & 1,2 & 1 & $0-5$ \\
& & 5 & & \\
\hline
\end{tabular}

Tabel 1 terdapat rata-rata umur responden adalah 30,8 tahun dan rata-rata paritas responden adalah 1,25 .

Tabel 2

Distribusi Rata-Rata Kecemasan Sebelum Intervensi Endorphine Massage pada Ibu Pre SC di Ruang Kebidanan RSUD EHD Tanjung Uban

\begin{tabular}{cccc}
\hline $\begin{array}{c}\text { Varia } \\
\text { bel }\end{array}$ & $\begin{array}{c}\text { M } \\
\text { ean }\end{array}$ & $\begin{array}{c}\text { Med } \\
\text { ian }\end{array}$ & $\begin{array}{c}\text { Min - } \\
\text { Max }\end{array}$ \\
\hline $\begin{array}{c}\text { Pre } \\
\text { intervensi }\end{array}$ & $\begin{array}{c}21, \\
85\end{array}$ & 22 & $14-28$ \\
\hline
\end{tabular}

Berdasarkan tabel 2 terdapat bahwa rata-rata kecemasan sebelum intervensi endorphine massage adalah 21,85 dan median 22.

Tabel 3

Distribusi Rata-Rata Kecemasan Sesudah Intervensi Endorphine Massage pada Ibu Pre SC di Ruang Kebidanan RSUD EHD Tanjung Uban

\begin{tabular}{cccc}
\hline $\begin{array}{c}\text { Varia } \\
\text { bel }\end{array}$ & $\begin{array}{c}\text { M } \\
\text { ean }\end{array}$ & $\begin{array}{c}\text { Med } \\
\text { ian }\end{array}$ & $\begin{array}{c}\text { Min - } \\
\text { Max }\end{array}$ \\
\hline $\begin{array}{c}\text { Post } \\
\text { intervensi }\end{array}$ & $\begin{array}{c}12, \\
85\end{array}$ & 12,5 & $10-15$ \\
\hline
\end{tabular}

Berdasarkan tabel 3 terdapat bahwa ratarata skor kecemasan setelah intervensi endorphine massage adalah 12,85 dan median 12,5 .

\section{Tabel 4}

Pengaruh Endorphine Massage Terhadap Penurunan Skor Kecemasan pada Ibu Pre Sectio Caesarea di Ruang Kebidanan RSUD EHD Tanjung Uban

\begin{tabular}{|c|c|c|c|c|}
\hline $\begin{array}{l}\text { Varia } \\
\text { bel }\end{array}$ & $\begin{array}{c}M \\
\text { ean }\end{array}$ & $\begin{array}{c}\text { Me } \\
\text { dian }\end{array}$ & $D^{S}$ & $\begin{array}{c}p \\
- \\
\text { value }\end{array}$ \\
\hline Sebel & 21 & 22 & 3 & \\
\hline $\begin{array}{l}\text { um } \\
\text { intervensi }\end{array}$ &, 85 & & ,56 & 0 \\
\hline $\begin{array}{l}\text { Setela } \\
\text { h } \\
\text { intervensi }\end{array}$ & $\begin{array}{l}12 \\
, 85\end{array}$ & 12,5 & ${ }^{1}$ & 000 \\
\hline
\end{tabular}


Hasil analisis tabel 4 menunjukkan bahwa rata-rata skor kecemasan sebelum endorphine massage adalah 21,85 sedangkan rata-rata skor kecemasan sesudah endorphine massage adalah 12,85 , sehingga mengalami penurunan rata-rata skor kecemasan yaitu sebesar 9. Hasil analisis Wilcoxon test lebih lanjut didapatkan nilai $\mathrm{p}=0,000(\mathrm{p}<0,05)$, dimana ada perbedaan rata-rata skor kecemasan sebelum dengan sesudah endorphine massage pada ibu pre section caesarea di RSUD Engku Haji Daud Tanjung Uban. Artinya ada pengaruh endorphine massage terhadap penurunan kecemasan pada ibu pre section caesarea di RSUD Engku Haji Daud Tanjung Uban.

Pelayanan rawat inap yang ada di RSUD Engku Haji Daud meliputi ruang rawat penyakit dalam, ruang rawat anak, ruang rawat bedah, ruang kebidanan, perinatologi, ICU, dan rawat inap pasien jiwa. Dokter spesialis obgyn berjumlah 2 orang, jumlah bidan sebanyak 14 orang dan telah memiliki sertifikat APN sebanyak 10 orang. Ruang kebidanan terdiri atas unit VK sebanyak 2 tempat tidur dan unit post partum sebanyak 9 tempat tidur. Rata-rata BOR ruang kebidanan tahun 2020 adalah 43\%. Angka persalinan dengan sectio caesarea lebih tinggi dibandingkan dengan persalinan normal. Pada bulan Desember 2020 angka pertolongan persalinan melalui sectio caesarea adalah sebanyak 40 orang $(75,5 \%)$ dari 53 pasien yang dirawat.

Intervensi yang dilakukan bidan untuk mengatasi kecemasan ibu pre operasi Sectio Caesarea adalah dengan meminta support suami dan keluarga, serta komunikasi terapeutik dengan pasien. Belum ada intervensi khusus yang dilakukan oleh bidan untuk mengurangi kecemasan pada ibu. Penelitian tentang intervensi endorphine massage untuk mengatasi kecemasan pada ibu pre operasi SC di RSUD Engku Haji Daud Tanjung Uban belum pernah dilakukan sebelumnya.

\section{Sebelum dilakukan endorphine massage pada ibu pre SC di RSUD EHD}

Hasil penelitian terdapat bahwa rata-rata skor kecemasan sebelum intervensi endorphine massage adalah 21,85, skor kecemasan terendah adalah 14 dan tertinggi adalah 28. Dari 20 orang responden sebanyak 1 orang $(5 \%)$ mengalami kecemasan ringan, sebanyak 14 orang $(70 \%)$ mengalami kecemasan sedang dan sebanyak 5 orang $(25 \%)$ mengalami kecemasan berat.

Hasil ini menunjukkan bahwa tingkat kecemasan pasien pre SC di RSUD EHD berada pada rentang tingkat kecemasan ringan sampai dengan berat. Hal ini mungkin dipengaruhi oleh tingkat pendidikan responden dimana sebanyak sebanyak 17 orang $(85 \%)$ responden memiliki tingkat pendidikan SMA. Ibu dengan tingkat pendidikan SMA dimungkinkan memiliki tingkat pengetahuan yang cukup dalam mengelola rasa cemasnya menghadapi operasi [24]

Saat persiapan pra Sectio Caesarea, pasien akan dibayangi saat pembiusan, proses pembedahan, kesejahteraan bayi dan keselamatan ibu, rasa sakit serta kendala lainnya yang menyebabkan rasa tidak nyaman dan mengakibatkan kecemasan. Kecemasan menjelang persalinan dapat berupa rasa takut kematian ibu dan bayinya, keadaan patologis atau ketakutan keadaan patologis dan lahir cacat rasa serta rasa bersalah terhadap orang tua atau dosa-dosa masa lalu [4]

Menurut hasil penelitian dari Widiastini (2017) yang berjudul "Pengaruh Massage Endorphin Terhadap Kecemasan Ibu Hamil Dalam Menghadapi Proses Persalinan Di Puskesmas Denpasar Utara III" didapatkan hasil rata-rata kecemasan sebelum endorphine massage pada kelompok kontrol sebesar 22,73 sedangkan pada kelompok intervensi sebesar 22,20. Hasil menunjukkan bahwa rata-rata kecemasan pada pada kelompok kontrol dan kelompok intervensi tidak jauh berbeda [20]

Kecemasan dalam menghadapi persalinan tidak hanya dialami oleh ibu yang akan menjalani persalinan dengan operasi Sectio Caesarea. Kecemasan juga dapat terjadi pada ibu yang akan menjalani persalinan secara normal. Hasil yang sejalan juga didapatkan dari Dian tahun 2017 dengan judul "Pengaruh Massage Endorphin terhadap Penurunan Tingkat Kecemasan pada Persalinan Kala I di 
Wilayah Kerja Puskesmas Kecamatan Kemiri". Hasil penelitian didapatkan ibu bersalin kala 1 mayoritas mengalami kecemasan berat yaitu sebanyak 16 orang $(50 \%) \cdot[25]$

Kecemasan yang dialami pasien dapat dilihat dari tanda dan gejala seperti: meningkatnya detak jantung, telapak tangan lembab, gelisah, gerakan-gerakan tangan yang tidak terkontrol, menanyakan pertanyaan yang sama berulang kali, isomnia, sering buang air kecil dan lain-lain [24]

\section{Sesudah dilakukan endorphine massage pada ibu pre SC di RSUD EHD}

Berdasarkan penelitian menunjukkan bahwa rata-rata skor kecemasan setelah intervensi endorphine massage adalah 12,85 dan median 12,5, skor kecemasan terendah adalah 10 dan tertinggi adalah 15. Dari 20 responden, sebanyak 17 orang (85\%) mengalami kecemasan ringan, dan sebanyak 3 orang $(15 \%)$ tidak mengalami kecemasan. Hasil ini sejalan dengan hasil penelitian Rohman, dkk (2019) dimana setelah diberikan endorphin massage mayoritas kecemasan ibu turun menjadi tingkat kecemasan ringan sebanyak 13 responden $(72,2 \%)$.

Endorphine massage merupakan cara melalui sentuhan ringan yang digunakan untuk mengurangi kesakitan. metode ini dapat digunakan untuk mengurangi ketidaknyamanan saat menjalani persalinan dan merelaksasi melalui permukaan kulit [12]

Teknik non farmakologi Endorphine massage adalah metode sentuhan ringan yang diberikan pada pasien bersalin. Endorphine massage juga meningkatkan perasaan tenang dan nyaman saat akan bersalian maupun saat persalinan berlansung. Endorphine merupakan sebuah zat didalam tubuh yang memiliki banyak kegunaan dari kombinasi morphine dan endogenous yang merupakan unsur protein yang di hasilkan oleh syaraf dan sel-sel tubuh manusia. Sentuhan massage bisa menstimulasi tubuh untuk mengeluarkan endorphine yang merupakan dapat memberikan kenyamanan dan pereda rasa sakit [12]

\section{Analisis Hamington Rating Scale for}

Anxiety sebagai alat ukur yang digunakan menunjukkan bahwa ibu mengalami setengah dari gejala kecemasan sebelum menjalani operasi seperti adanya rasa ketegangan menghadapi persalinan, perasaan mudah tersinggung dan firasat buruk lainnya adalah sebanyak 14 (70\%) sebelum intervensi naik menjadi 19 (95\%) setelah intervesi endorphine massage.

Disamping itu, sebelum intervensi endorphine massage sebanyak 15 orang $(75 \%)$ dari responden menyatakan bahwa ibu mengalami setengah dari gejala ketegangan yang ada seperti gelisah, gemetar, mudah terkejut, tidak bisa istirahat dengan tenang atau perasaan lesu. Namun setelah intervensi endorphine massage sebanyak 19 orang (95\%) ibu hanya merasakan satu diantara gejala ketegangan di atas.

Dan sebelum intervensi endorphine massage sebanyak 15 orang (75\%) dari responden menyatakan bahwa ibu mengalami setengah dari gejala gangguan autonomy sebelum operasi seperti mulut kering, mudah berkeringat, muka merah, pusing atau sakit kepala. Namun setelah intervensi endorphine massage sebanyak 6 orang $(30 \%)$ ibu yang masih merasakan gejala yang sama. Sisanya sebanyak 14 orang (70\%) ibu tidak mengalami gangguan autonomy lagi.

\section{Pengaruh endorphine massage terhadap penurunan kecemasan pada ibu pre SC di RSUD EHD}

Hasil uji Wilcoxon test menunjukkan nilai $\mathrm{p}$ $=0,000(\mathrm{p}<0,05)$, artinya ada perbedaan ratarata skor kecemasan sebelum dengan sesudah endorphine massage pada ibu pre SC di RSUD EHD Tanjung Uban. Hal ini dibuktikan oleh nilai rata-rata skor kecemasan sebelum intervensi endorphine massage adalah sebesar 21,85, sedangkan rata-rata skor kecemasan sesudah intervensi endorphine massage adalah sebesar 12,85. Hasil ini menunjukkan selisih rata-rata skor kecemasan sebesar 9.

Hal ini sejalan dengan penelitian Sukmaningtyas and Windiarti n.d tahun 2017 Dengan hasil bahwa teknik massage dapat membuat perasaan nyaman pada ibu hamil, 
rileks dan fresh selama persalinan berlangsung. Hal ini disebabkan karena pinatan dapat menstimulasi tubuh melepaskan endorphin yang menormalkan detak jantung, mengendalikan stress, mengurangi rasa nyeri dan menghasilkan kenyaman melalui permukaan kulit [25].

\section{KESIMPULAN}

a. Rata-rata skor kecemasan ibu pre SC sebelum diberikan intervensi endorphine massage adalah 21,85

b. Rata-rata skor kecemasan ibu pre SC setelah diberikan intervensi endorphine massage adalah 12,85

c. Ada pengaruh pemberian teknik endorphine massage terhadap penurunan kecemasan pada ibu pre Sectio Caesaria di RSUD EHD Tanjung Uban $(\mathrm{p}=0,000 ; \mathrm{p}<0,05)$.

\section{DAFTAR PUSTAKA}

[1] Oxom \& Forte, Ilmu Kebidanan Patologi dan Fisiologi Persalinan. Yogyakarta: Andi Offset, 2010.

[2] \& I. G. Warsono, Fahmi FY, "Pengaruh Pemberian Teknik Relaksasi Benson terhadap Penurunan Intensitas Nyeri Pasien Post Sectio Caesarea di RS PKU Muhammadiyah Cepu," J. Ilmu Keperawatan Med. Bedah, vol. 2, no. 1, 2019.

[3] Kementerian Kesehatan Republik Indonesia, "Riset Kesehatan Dasar Nasional," 2018.

[4] L. Arianti, Diana., \& Restipa, "Pengaruh Endorphine Massage Terhadap Tingkat Kecemasan Ibu Primigravida," J. Ilmu Kesehat., vol. 3, no. 2, 2019.

[5] D. Hawari, Manajemen Stress, Cemas, dan Depresi. JAKARTA: FKUI, 2011.

[6] Natsir \& Munith, Dasar-Dasar Keperawatan Jiwa. JAKARTA: Salemba Medika, 2011.

[7] Purwaningsih. Ira, "Gambaran Program Perencanaan Persalinan Dan Pencegahan Komplikasi (P4k) Pada Ibu
Hamil Trimester Iii Di Puskesmas Jetis I," Stikes Jenderal Achmad Yani, 2016.

[8] K. Afiyah, "Demonstrasi Endorphin Massage Untuk Mengurangi Kecemasan Menghadapi Persalinan Pada Primigravida Di Poli KIA RS Islam Surabaya," 2019.

[9] G. . \& S. Stuart, Buku Saku Keperawatan Jiwa, 5th ed. JAKARTA: EGC, 2012.

[10] K. Koren, "Deep Tissue Massage: What Are Talking About?" Journal of Bodywork \& Movement Therapies," 2017.

[11] P. . Sukmaningtyas, W.,\& Windiarti, "Efektivitas Endorphine Massage Terhadap Tingkat Kecemasan Ibu Bersalin Primipara," Bidan Prada J. Publ. Kebidanan Akbid YLPP Purwokerto, vol. 7, no. 1, 2016.

[12] Y. Aprillia, Siapa Bilang Melahirkan Itu Sakit. . Yogyakarta: Andi Offset, 2010.

[13] P. P. N. Ekawijayanti, "Pemberian Endorphin Massage Mempengaruhi Kesiapan Psikologi Ibu Hamil TM III Dalam Menghadapi Persalinan di BPM NWB Kintamawani," J. Dunia Kesehat., vol. Vol 5, no. Nomor 2, p. pages 5, 2016.

[14] Rasjidi, Manual Seksio Sesarea Dan Laparotomi Kelainan Adneksia, 1st ed. Sagung Seto, 2011.

[15] C. Effendy, Kiat Sukses Menghadapi Operasi. Sahabat Setia, 2015.

[16] Yusuf, Buku Ajar Keperawatan Kesehatan Jiwa. Jakarta: Salemba Medika, 2015.

[17] M. F. Mongan, Hypno Birthing: Metode Melahirkan secara Aman, Mudah dan Nyaman. PT. Bhuana Ilmu Populer., 2011.

[18] A. Rohmah, Afifatu., Hendarsih, Sri., \& dan Ratnawati, "Pengaruh Pemberian Endorphin Massage Terhadap Tingkat Kecemasan Pasien Pre Sectio Caesarea Di RSU Siaga Medika Banyumas," 2019.

[19] D. Arianti and L. Restipa, "Pengaruh Endorphine Massage Terhadap Tingkat 
Kecemasan Ibu Primigravida," J. Ilmu Kesehat., vol. 3 Nomor 2, 2019.

[20] L. P. Widiastini, "Pengaruh Massage Endorphin Terhadap Kecemasan Ibu Hamil Dalam Menghadapi Proses Persalinan Di Puskesmas Denpasar Utara III," 2017.

[21] S. Rahayu, M. N. Widyawati, and R. K. Dewi, "Pengaruh Masase Endorphin Terhadap Tingkat Kecemasan dan Involusio Uteri Ibu Nifas," $J$. KEBIDANAN, 2018.

[22] D. Restianti, Herniatun, and D. Santoso, "Perbandingan Efektifitas Antara Pijat Endorfin Dengan Aromaterapi Lavender Terhadap Intensitas Nyeri Pasca Sectio Caesarea," Sekolah Tinggi Ilmu Kesehatan Muhammadiyah Gombong, 2017.

[23] S. Wuryani, D. Qur'ani, N. Fatmawati, and R. Aprilia, "Pengaruh Terapi Relaksasi Massage Punggung Terhadap Penurunan Tingkat Kecemasan Pada Pasien Pre Operasi Bedah Mayor Di SMC RS Telogorejo," J. Ilmu Keperawatan dan Kebidanan, vol. 7, no. 1, pp. 1-8, 2015.

[24] \& H. O. Pawatte, I, Cicilia P, "Perbedaan Tingkat Kecemasan pada Ibu Pre Seksio Caesarea di RSIA Kasih Ibu dan RSUP Prof.Dr.R.D. Kondou Manado," J. Kesehat. Komunitas dan Trop., vol. 1, no. 3, 2013.

[25] R. Rahayu, S., Widyawati, MN., \& Dewi, "Pengaruh Masase Endorphin terhadap Tingkat Kecemasan dan Involusio Uteri Ibu," J. Kebidanan, vol. 8, no. $1,2018$. 